\title{
PROJECT-BASED SCIENCE LEARNING AND PRE-SERVICE TEACHERS' SCIENCE LITERACY SKILL AND CREATIVE THINKING
}

\author{
Kartika Chrysti Suryandari', Sajidan ${ }^{2}$, Sentot Budi Rahardjo ${ }^{3}$, \\ Zuhdan Kun Prasetyo ${ }^{4}$, and Siti Fatimah ${ }^{5}$ \\ ${ }^{1,2,5)}$ Faculty of Teacher Training and Education Program, Universitas Sebelas Maret Indonesia, \\ 3) Faculty of Science, Universitas Sebelas Maret Indonesia, \\ 4) Faculty of Science, Yogyakarta State University \\ E-mail: sajidan@fkip.uns.ac.id : kartika@fkip.uns.ac.id
}

\begin{abstract}
This study set out to examine the effectiveness of project-based science learning towards pre-service teachers literacy skills and learning creativity in wave and optical materials. This quasiexperimental study involved 115 students of Primary Teacher Education Program, Universitas Sebelas Maret Surakarta. Direct and in-depth data dissemination techniques were used in this study. The aspects of creative thinking abilities include fluency, authenticity, elaboration, and flexibility. Mann Withney $\mathrm{U}$ test was used to test the hypothesis, while the N-Gain test was performed to determine the preservice teachers improvement in scientific literacy skills and creative thinking. Both qualitative and quantitative data analyses were performed in this study. The results showed that: 1) material and optical tools-based learning activities are appropriate for the pre-service teachers scientific literacy skills and creative thinking. The correct answer term includes the highest average probability statistics from other subindicators; 2) aspects of science that are used in the aspects of literacy is in good category but the originality aspect in its ability needs to be developed and processed continuously.
\end{abstract}

Keywords: science literacy skill, creative thinking skill, project based learning, waves and optics

\section{PENGARUH PEMBELAJARAN SAINS BERBASIS PROYEK TERHADAP KETERAMPILAN LITERASI ILMU DAN PEMIKIRAN KREATIF CALON GURU}

\begin{abstract}
Abstrak: Penelitian ini bertujuan untuk mengukur keefektifan pembelajaran sains berbasis proyek terhadap keterampilan literasi dan kreativitas belajar dalam materi gelombang dan optik. Penelitian ini dilakukan secara eksperimen semu. Subjek penelitian ini adalah 115 siswa semester Program Pendidikan Guru Pratama, Universitas Sebelas Maret Surakarta. Teknik penyebaran data langsung dan mendalam. Aspek kemampuan berpikir kreatif meliputi kelancaran, keaslian, elaborasi, dan fleksibilitas. Untuk menentukan besarnya peningkatan keterampilan literasi sains dan siswa berpikir kreatif digunakan N-Gain Test hipotesis menggunakan tes Mann Withney U. Analisis data dilakukan secara kualitatif dan kuantitatif. Hasil penelitian menunjukkan bahwa: 1) kegiatan pembelajaran berbasis material dan alat optik sesuai untuk keterampilan literasi sains dan pemikiran kreatif siswa. Istilah jawaban yang benar mencakup statistik probabilitas rata-rata tertinggi dari subindikator lainnya; 2) aspek ilmu yang digunakan dalam aspek literasi dalam aspek yang baik tetapi aspek orisinalitas dalam kemampuannya perlu dikembangkan dan diolah terus- menerus.
\end{abstract}

Kata kunci: keterampilan literasi sains, keterampilan berpikir kreatif, pembelajaran berbasis proyek, gelombang dan optik

\section{INTRODUCTION}

Life skills on 21 st century needed for the Indonesian people are critical thinking skills, creative, communicative, problem solving and literacy culture. To build a culture of literacy, especially in the realm of education, since 2016 the Ministry of Education and Culture has intensified the National Literacy Movement. The culture of literacy in question is a culture of reading and writing that is expected to improve the quality of human resources. However, based on the results of the 2015 Education For All (EFA) study, it was explained that there was a decline in literacy in Indonesia. This was confirmed by 
the results of UNESCO's statistical data in 2012 which stated that the reading interest index in Indonesia had only reached 0.001 . This means that every 1,000 residents only one person who has a reading interest (Education For All 2015). Thus, the national average of each individual is not up to one book title per person per year that is read. As a comparison, regions in Indonesia that have the highest reading interest are DIY. Then based on the data from PISA in 2015, the average score of student science literacy in Indonesia was 382 with the average scientific literacy of all participating countries following the 2009 PISA of 403. These results show that Indonesian students' scientific literacy is still low and far away below average, even Indonesia's position in the 2015 PISA countries has an average of low scientific literacy, which is in rank 64 of 72 participating countries (OECD, 2015).

One effort that needs to be done in developing literacy is by directing children to get used to reading. In the world of education, especially in schools or colleges, literacy development should be carried out effectively and efficiently. However, based on observations to students of the third semester on Primary Teacher Education Program 2016/2017 the activity of reading journals is still in the low category. The results of the analysis of lecture assignments and practicum reports, $100 \%$ of students still use references derived from blogs / wordpress / middle school books. The search for reference sources in the form of scientific works such as journals and proceedings or final assignments (thesis, thesis, dissertation) is still not used as the main reference in working on a task or to add scientific insight.

Based on the results of the interview, students are still experiencing confusion in finding reference sources in the form of journals or scientific works, such as searching the journal website. This is because during learning, students have not been accustomed to finding, reading, and analyzing references in the form of journals both nationally and internationally.

Literacy is important in the development of the world, especially in the face of the 21 st century. According to Wakhidah (2012), skills in the 21 st century that need to be mastered by someone include critical thinking skills, problem solving skills, creative thinking skills, decision making skills, reflective reading and writing skills, communication skills both orally and in writing. These skills are expected to always be developed in every learning so that students are able to face the challenges of the global world.

Science is a branch of science that can develop skills in the 21 st century. Chiappetta \& Kobbala (2010) explains that science must be viewed from four dimensions, namely science as a way of thinking, science as a way to investigate, science as the body of knowledge, science and its interaction with technology and society. Therefore, in science learning activities must cover these four dimensions with the aim of fostering students with scientific literacy. According to Rahayuni (2016), scientific literacy is a very important thing to be mastered by every individual because this is closely related to one's understanding of the environment and other problems faced by modern society that are very dependent on the development of science and technology, including also social problems. Learning science that directs students to become literate towards science must have the ability to think critically, creatively and solve problems. Ministry of National Education (2011) and Winarni (2012) explained that science learning that should be done is learning that can prepare students to be knowledgeable in science and technology, able to think logically, be able to think critically, creatively, and solve problems in real life. Based on some of these explanations it can be implied that the goal of learning science in addition to creating students with scientific literacy, is also able to create students who have the ability to think creatively.

Fathurohman (2014) explained that students' scientific literacy abilities can be influenced by several factors, namely learning methods and models by the teacher, education curriculum and system, learning facilities and infrastructure, learning resources, and teaching materials. Factors that directly intersect with students' learning activities are the selection of learning methods and models by educators. Cahyana (2017) explains the factors that need to be considered to develop scientific literacy is to attract the involvement of students in learning and create a pleasant learning atmosphere, thus making students learn to be ready to learn and better at understanding science. One method that can be effectively used in science learning (physics) is the project method (Roziqin, Lesmono, and Bachtiar: 2018). 
Hendrik \& Ihtiari (2016) explained that the project learning process in an application supports the development and improvement of students' critical thinking skills. Furthermore, Sumarni (2015) states that through projects, students do not have to memorize any theory or equation (formula), but rather analysis and critical thinking by analyzing the information gathered to solve problems through the project. This pragmatic approach concentrates more on processes than content. Based on this explanation, the project method can be used as one method that can be used in developing creative thinking skills and scientific literacy abilities of students, especially in wave material and optical devices.

Some of the research that has been done on project-based learning in developing scientific literacy skills and creative thinking, among others, is Afriana's research (2016) which yields findings that project-based learning with the STEM approach can improve science literacy of junior high school students on the theme of air pollution compared to classes without using learning. project based on the STEM approach. The improvement of scientific literacy skills of male and female groups both increased with the average N-Gain in the medium category for aspects of knowledge and competence.

Research from Rohana \& Wahyudin (2017) resulted in findings that project-based learning can improve students' creative thinking skills significantly higher than the expository class, with the average value of N-Gain in the experimental class in the high category and the average value of $\mathrm{N}$-Gain in the control class is in the low category. Furthermore, research from Fatimah (2018) produced findings that projectbased science learning has a significant effect on students' creative thinking skills. Creative thinking skills of students who use free project based learning are better than those using guided project based learning.

Based on the background explanation above, this study aims to determine the effectiveness of project-based learning in improving scientific literacy skills and students' creative thinking skills in wave and optical material.

\section{METHOD}

This research is a quasi-experimental research conducted at Primary Education
Program VI Kebumen, Universitas Sebelas Maret on students with 3 classes/groups. Research design using Pre Test-Post test Control Group Design. The sampling technique uses simple random sampling where the three classes are randomized and two classes are taken as the research sample.

Table 1. Research Design

\begin{tabular}{cccc}
\hline Group & Pretest & Treatment & Posttest \\
\hline A & $\mathrm{O}_{1}$ & $\mathrm{X}_{1}$ & $\mathrm{O}_{2}$ \\
B & $\mathrm{O}_{1}$ & $\mathrm{X}_{2}$ & $\mathrm{O}_{2}$ \\
\hline
\end{tabular}

Group A is the experimental 1 which is treated using the project method, while group B is the experimental II which is given a conventional method treatment that is only using the discussion method. Project-based science learning is divided into three themes, namely light waves, sound waves, and optical devices. The project theme on the concept of light and optical devices consists of holograms, kaleidoscopes, periscopes, and telescopes. The project theme on the wave and sound concept is sound resonance and mathematical pendulum. The project is completed in groups and within 1 month.

Instruments of scientific literacy abilities and creative thinking abilities are measured by tests in the form of essays totaling 10 items. The form of the problem of scientific literacy ability adapts from the development of the Test of Scientific Literacy Skills (TOSLS) by Gormally (2012). Tests of creative thinking skills include fluency, originality, elaboration, and flexibility (Torrance, 1990; Alghafri, Rashid and Salim. 2014).

Data analysis using Mann-Whitney $U$ test with provisions if the $\mathrm{p}$-value is $<0.05$, then the null hypothesis is rejected. Furthermore, to determine the magnitude of improvement in scientific literacy skills and creative thinking students use N-Gain with the following classifications.

Table 2. N-Gain Classification

\begin{tabular}{cc}
\hline Average N-Gain & Classification \\
\hline $0,70<N$-Gain $\leq 1,00$ & High \\
$0,30<N$-Gain $\leq 0,70$ & Medium \\
$N$-Gain $\leq 0,30$ & Low \\
\hline (Source: Hake, 2007) &
\end{tabular}

(Source: Hake, 2007) 


\section{RESULTS AND DISCUSSION}

\section{A. Results}

Based on the results of data analysis, project-based learning can be used to develop and improve scientific literacy skills and creative thinking of students.

Table 3. Mann Withney U Test Summary Results

\begin{tabular}{lcc}
\multicolumn{3}{c}{ Test Statistics $^{\mathrm{a}}$} \\
\hline & literacy post & creative post \\
\hline Mann-Whitney U & 312.500 & 276.000 \\
Z & -2.034 & -2.574 \\
Asymp. Sig. (2-tailed) & .042 & .010 \\
\hline
\end{tabular}

There is effectiveness of project-based learning on scientific literacy skills and creative thinking of students on wave and optical material.

Table 4. Summary of Average Project Class $\mathrm{N}$-Gain Values

\begin{tabular}{lcc}
\hline \multicolumn{1}{c}{ Variable } & $\begin{array}{c}\text { Average } \\
\text { N-Gain Value }\end{array}$ & Category \\
\hline $\begin{array}{l}\text { Science Literacy Ability } \\
\text { Creative Thinking }\end{array}$ & 0,45 & Medium \\
Ability & 0,38 & Medium \\
\hline
\end{tabular}

Project learning is able to improve scientific literacy skills and the ability to think creatively in students with moderate (good enough) categories.
Table 5. Summary of Average N-Gain Value for Conventional Classes

\begin{tabular}{lcc}
\hline \multicolumn{1}{c}{ Variable } & $\begin{array}{c}\text { Average } \\
\text { N-Gain Value }\end{array}$ & Category \\
\hline Science Literacy Ability & 0,28 & Low \\
Creative Thinking & 0,30 & Low \\
Ability & & \\
\hline
\end{tabular}

Conventional learning is less able to improve scientific literacy skills and students' creative thinking skills.

Students' literacy abilities on indicators organize, analyze and interpret quantitative data and scientific information better than indicators of student literacy ability to understand inquiry methods that lead to scientific knowledge.

There were differences in student literature search before and after project-based learning. The form of searching data in the form of journals and proceedings is the highest type of literature search compared to other types of literature during project learning, while the literature in the video is the second afterthejournal/proceedings.

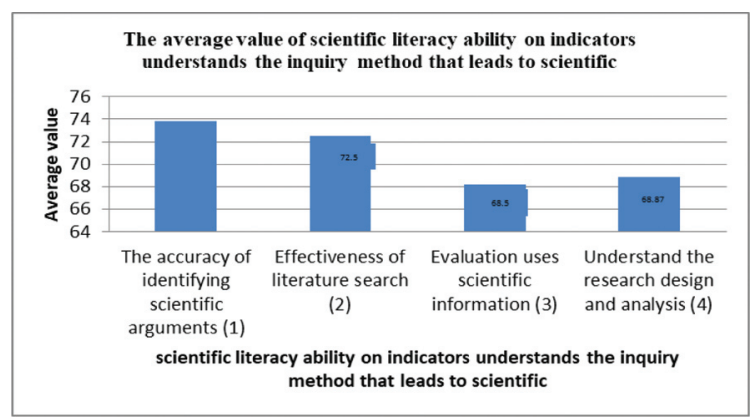

Figure 1. Analysis of the average value of scientific literacy skills in indicator I

Table 6. Results of analysis of students' scientific literacy abilities

\begin{tabular}{ccc}
\hline No & Indicator of Science Literacy Ability & Average Test Value \\
\hline 1 & Understanding inquiry methods that lead to scientific knowledge & 70,85 \\
2 & Organizing, analyzing and interpreting quantitative data and scientific information & 82,38 \\
\hline & Average Score of Science Literacy Ability & 76,61 \\
\hline
\end{tabular}

Table 7. Types of Student Literature Search Before and After Project-Based Learning

\begin{tabular}{clcc}
\hline No & \multicolumn{1}{c}{ Type of Literature } & before $(\%)$ & after (\%) \\
\hline 1 & Buku & 25 & 3 \\
2 & Proceedings / journals & 13 & 90 \\
3 & Internet (blog, wordpress, ect) & 40 & 0 \\
4 & Video (youtube, ect) & 5 & 7 \\
5 & Direct observation & 10 & 0 \\
6 & Final Project (Thesis, thesis, dissertation) & 0 & 0 \\
7 & Dictate / module & 7 & 0 \\
\hline \multicolumn{1}{c}{ Total } & 100 & 100 \\
\hline
\end{tabular}


Figure 1 shows the indicator I with the sub indicators identifying the right scientific arguments showing higher average values than other subindicators, while the subindicators on evaluations in using scientific information show the lowest average value.

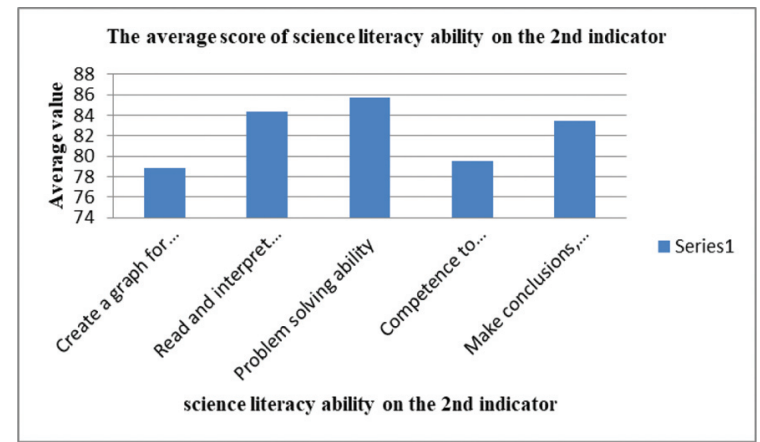

Figure 2. Average Value of Science Literacy Ability in Indicator II

Figure 2 shows that the average value of scientific literacy ability in indicator II problem solving subindicators using quantitative capabilities including probability statistics get the highest average value than other subindicators. This is indicated by quite a lot of students who can work on the problem in this subindicator correctly and precisely, while in the subindicator making a graph that can interpret the data shows the lowest average value.

Based on the results of the analysis of the test answers there are still many students who are less precise in describing the dependent variable and the independent variable on each $\mathrm{x}$ axis and $y$ axis. Then there is a lack of information on each $\mathrm{x}$-axis and $\mathrm{y}$-axis. This is corroborated from the results of interviews and questionnaires that $78 \%$ of students find it difficult to determine independent variables and dependent variables that must be presented in the form of graphs, tables, and diagrams. In addition, students also find it difficult to interpret special rays on lenses and mirrors in the form of images.

Figure 3 is a form of literacy ability that comes from valid sources / sources such as in scientific journals. Inclusion of sources used in this language can also be used and valid or not.

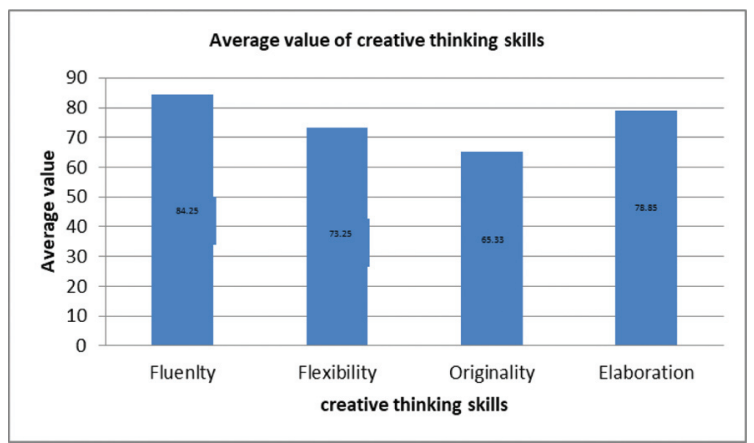

Figure 4. Average Value of Aspects of Creative Thinking Ability

Table 4 shows the average value of students' creative thinking ability with fluency aspects resulting in higher average values than other aspects. Based on the results of the analysis of student answers, students gave quite a lot of answers that varied but had the same meaning, meaning students could be said to be correct in answering questions.

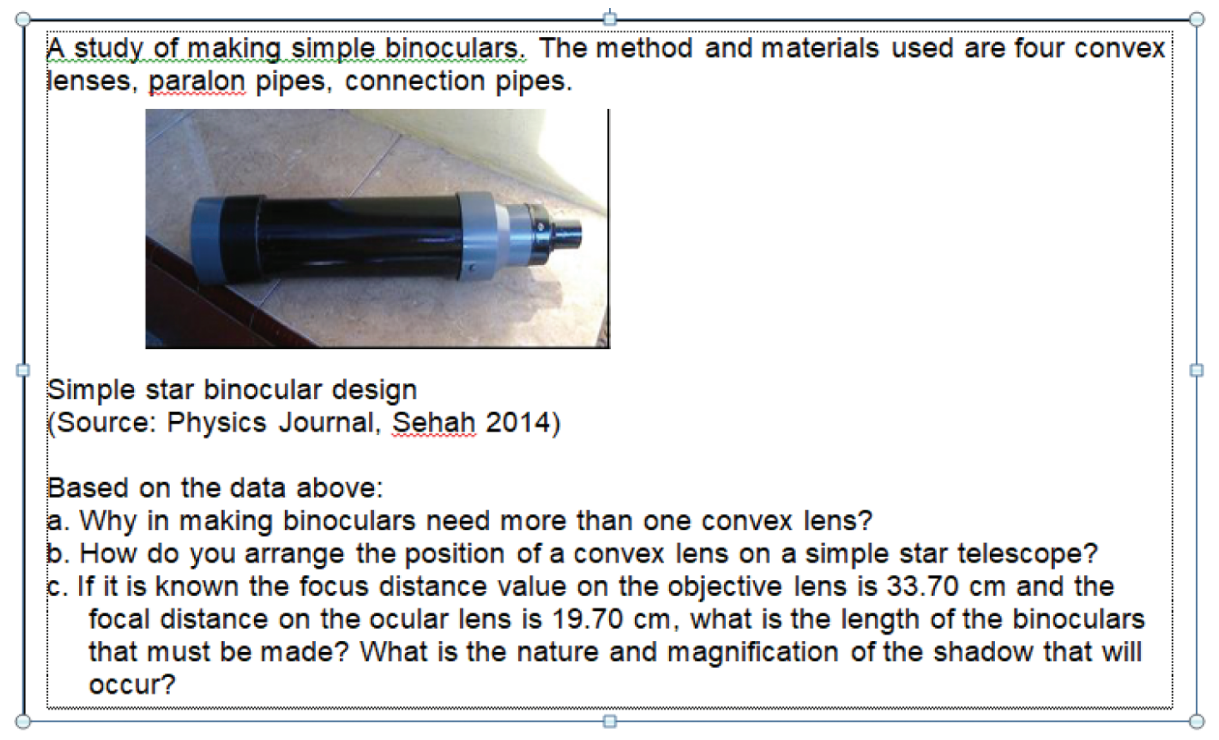

Figure 3. Examples of Forms of Scientific Literacy Ability Test Questions 


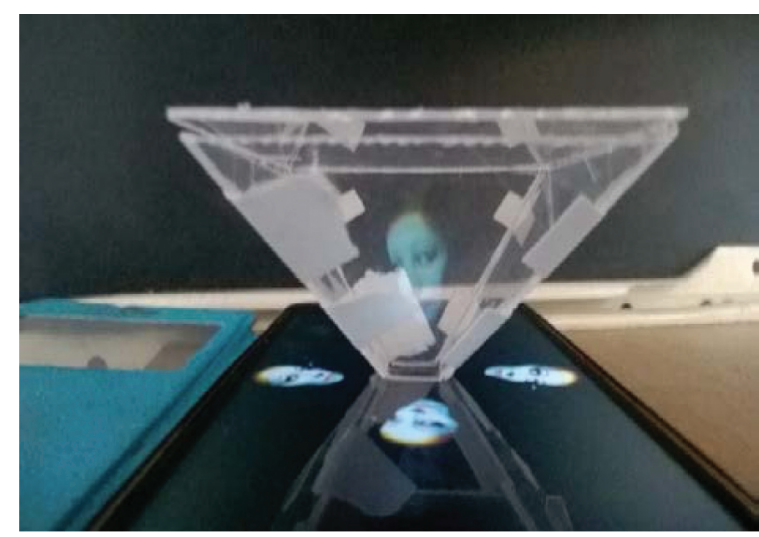

Figure 5. Results of the hologram project

Figure 5 is a product of students with a hologram theme. This product describes the concept of reflection, diffraction, and interference and the amplitude and phase of the wave. In addition to holograms, students also produce products namely kaleidoscope, periscope, telescope, resonance tube to determine the velocity value of sound waves in the air, and mathematical pendulum to prove the value of Earth's gravitational acceleration.

Based on table 8 , there are similarities in the project learning process with students' scientific literacy skills and creative thinking. At the stage of giving questions at the beginning of learning is able to develop scientific literacy skills and creative thinking in terms of identifying and analyzing students' arguments from various points of view.

Table 9 shows students' perceptions during the project learning process, namely that in searching literature is the easiest activity to do, while making a practicum report is an activity that is considered the most difficult to do. Based on the results of analysis and observation, even though students have the ease of accessing journals or scientific works, in terms of analyzing journal contents, they need to be improved. While in the case of making project reports students still find it difficult if they have to fit the format of scientific work, starting from the making of the title to the writing of the right bibliography. Title making must contain at least independent variables and be bound if the project produces quantitative data such as resonance tubes and mathematical pendulum. Students still have difficulty in determining the variables during the innovation practicum, and evaluating the results of the lab to be better.

\section{Discussion}

Project-based learning begins with brainstorming through the provision of interesting and challenging questions and adapted to real life such as, "why does the sky during the day look

Table 8. Project-based learning relationships with scientific literacy skills and students' creative thinking skills

\begin{tabular}{llc}
\hline \multicolumn{1}{c}{ Syntax PjBL } & \multicolumn{1}{c}{ Development of Science Literacy Ability } & $\begin{array}{c}\text { Development of Creative } \\
\text { Thinking Ability }\end{array}$ \\
\hline $\begin{array}{l}\text { Starts With the Essential } \\
\text { Question }\end{array}$ & Identify appropriate scientific arguments & Fluency \\
$\begin{array}{l}\text { Design a Plan for the Project } \\
\text { Creates } \text { a Schedule }\end{array}$ & Use effective literature search & flexibility \\
Monitor the Students and the progress & Evaluation in using scientific information \\
of the Project & 1. Understanding the elements of research design \\
& and its impact on scientific findings & Originality\& flexibility \\
Assess the Outcome & 2. Read and interpret data (graphs, tables) & \\
& 1. Troubleshooting using quantitative capabilities & fluency \&flexibility \\
2. Understand and be able to interpret basic & \\
Evaluate the Experience & statistics & Flexibility \\
\end{tabular}

Table 9. Student Perceptions of PjBL Activities

\begin{tabular}{|c|c|c|c|c|c|c|c|c|c|}
\hline \multirow{2}{*}{ Level } & \multicolumn{9}{|c|}{ Name of activity } \\
\hline & 1 & 2 & 3 & 4 & 5 & 6 & 7 & 8 & 9 \\
\hline Easy $(\%)$ & 90 & 5 & 10 & 15 & 20 & 3 & 58 & 5 & 23 \\
\hline Medium (\%) & 10 & 43 & 30 & 27 & 62 & 20 & 32 & 7 & 40 \\
\hline Difficult (\%) & 0 & 52 & 60 & 58 & 18 & 78 & 10 & 88 & 37 \\
\hline Total & 100 & 100 & 100 & 100 & 100 & 100 & 100 & 100 & 100 \\
\hline
\end{tabular}


blue and in the afternoon orange?" Or "why does the thunder sound at night sound louder rather than lightning in the daytime? " These questions aim to explore students' initial knowledge of the wave concept, especially the concept of light and sound waves.

Initial information obtained from students is continued by giving questions to a higher level so as to train students to analyze answers to these questions and train students to solve a problem. Harper (2014) mentions project learning focusing on an in-depth investigation process involving a long and rigorous question and answer process, using resources and developing answers; and focused on open questions to understand and attract students' attention in capturing project assignments. Muskania \& Wilujeng (2017) suggested that learning using projects begins with providing problems that lead to the final product that will be produced by students.

After brainstorming, the next step students are given the task of creating and designing a project. During project design, students are directed to look for literature in valid sources and such as scientific journals and proceedings. Educators also provide freedom for students in making project designs that will be made in accordance with the literature that has been obtained. The freedom to innovate and be creative helps students in thinking about the best solutions in solving problems.

Project learning is able to train students in asking questions, thinking about different ways to solve problems, training students to categorize data, training students to think about things that are not thought of by others, and able to train students in expressing their own opinions against a problem. This is in line with the opinion of Mihardi, Harahap \& Sani (2013) that projectbased learning is able to train students to design, analyze, and apply students' ideas in making a project. While Fatimah (2018) explained that project-based learning provides students with greater opportunity to think and explore their ability to complete a task and find the right concept.

Activities during the project learning process take place significantly able to improve scientific literacy skills and creative thinking of students. This is in line with the research of Rohana \& Wahyudin (2017) which results in that project-based learning can improve students' creative thinking skills. Gunawan, Sahidu, Harjono, \& Suranti (2017) produced the same findings that learning using projects can increase students' creativity. While the findings of Afriana, Permanasari, \& Fitriani (2016) show that projectbased learning can improve students' scientific literacy skills. The development of creative thinking skills and scientific literacy of students during the project learning process is trained consistently and continuously by providing problems that must be solved by producing a product based on scientific literature obtained by students. Through this activity, students will be accustomed to exploring their thoughts and developing creative ideas.

This literature search is an important part of project learning. This is supported by Sumarni's (2015) statement that project-based learning is able to improve students' ability to search for and obtain information, students do not have to memorize any theory or equation (formula), but rather to search for information collected to solve problems through project creation. This pragmatic approach concentrates more on processes than content. During the project learning process students are always directed to find and analyze scientific literature. Chu (2011) also explained that project learning has a positive impact in developing reading and writing skills and technology literacy.

The process of searching and analyzing this literature became the main capital in developing students' scientific literacy skills during project learning. This is as stated by Susiati, Adisyahputra, \& Miarsyah (2018) that scientific literacy skills can be obtained by processing information critically and creatively through reading comprehension activities. A person who is limited in his ability to read will be very limited as well as the depth and breadth of understanding science. Therefore, students are required to read and search for literature that has been carefully and creatively obtained and critically reviewed. Morgil (2008) also suggested that in order to complete project assignments, students can search literature from various sources such as online, libraries, field visits, observations, etc. so that they can add student references in producing a creative and innovative product.

During the project learning process, educators do not provide knowledge directly, but 
provide freedom to students to make discoveries (inquiry) to get the knowledge that is expected to be done in teams / groups. While the task of the lecturer is to monitor and provide assistance to students in completing project assignments up to the making of scientific reports. Freedom in expressing ideas and ideas and problem solving during project completion is able to explore students' creative thinking abilities. This is in line with Capraro's (2013) research that project learning is able to help students solve problems and train students to think critically, analyze, and improve higher-order thinking skills. The ability to think creatively is one of the higherorder thinking abilities, namely the ability to think divergently (Birgili, 2015; Khashani, et all, 2017) which consists of four aspects, fluency; flexibility; originality; and elaboration. Istiyono, Dwandaru \& Rahayu (2018) suggests that creative thinking is a thought process that produces various possible answers when responding to problems given. Therefore, the project method is very relevant to be used to improve the ability to think creatively.

Collaborating with the team during project learning is a very important activity. Collaboration is one of the characteristics of project learning activities with the aim of helping students to exchange ideas / ideas and have good communication skills. As stated byAstawa,Artini, \& Nitiasih (2017) which explains that the stages of project learning train students to be active and creative thinkers and engage in cooperative learning to work together on projects. Projectbased learning allows students to gain deeper understanding of material by collaborating and using their ideas (active construction). Social interaction allows students to work with others to build shared knowledge. Williams (2017) explains that project-based learning provides opportunities for students to engage in active learning and opportunities to learn new soft skills such as collaboration, communication, and negotiation. See, Rashid, \& Bakar (2015) states that communication and teamwork skills are skills that can be trained through project activities. Harper (2014) continued that PjBL has important elements that can train 21 st century skills, one of which is communication skills.

The final stage of project-based learning is evaluating project activities that have been carried out. Based on the results of the interview, it was found that students felt happy and motivated in making the project that had been done. Students get more new knowledge and skills during project completion while feeling challenged to complete the project. This is as stated by Sumarni (2015) that one of the advantages of using PjBL in learning is that it can increase student motivation. Chiang \& Lee (2016) explained that the PjBL method is able to increase student learning motivation rather than traditional learning methods. While Suparno (2007) explained that one of the characteristics / characteristics of the project is the theme must challenge students and generally make something / product that is not commonly done. Although the project must be challenging, it is also required that it is not too difficult because it will have an impact on the time and outcome of the project completion.

Evaluation during project learning, among others, is: lack of time for project completion so that the time for conceptualization is less than optimal. Grant (2002) states that one of the disadvantages of $\mathrm{PjBL}$ is that it takes a long time to solve a complex problem. This results in a lack of time to explain some material / content for conceptualization. In addition, the habit of students only accepting material during lectures indirectly influences the way students think. Roziqin, Lesmono, \& Bachtiar (2018) explained several obstacles in project-based learning, namely students still find it difficult to work on project activities because they are accustomed to only receiving information directly from the teacher.

Based on observations, students find it difficult to complete the practicum report with a duration of 1 week. This is because students are not used to making reports in accordance with the format of scientific work. Furthermore, making the independent and bound variables still difficult for students so that the impact of this is their difficulty in making the project. Therefore, it is necessary to familiarize students to always write observations into scientific reports so that they are accustomed to writing a scientific work. In addition, when students often conduct discovery activities, students will be accustomed to analyzing independent variables and dependent variables or other variables. 


\section{CONCLUSION}

Based on the results of the analysis, it can be concluded that: 1) project-based learning on wave material and optical tools affect students' scientific literacy and creative thinking skills with a significance value of 0.046 and 0.000 ; 2) the improvement of scientific literacy skills shows a medium category with an average value of N-Gain 0.45 while an increase in students' creative thinking ability shows a low category with an average $\mathrm{N}$-Gain score of 0.28 ; 3) understanding aspects of inquiry methods that lead to scientific knowledge of scientific literacy abilities and aspects of originality in the ability to think creatively need to be developed. In addition to using the PjBL model, scientific literacy and creative thinking skills can be measured using the STEM (Science, Technology, Engineering, and Mathematics) approach.

\section{ACKNOWLEDGEMENT}

The authors would like to thank the Institute of Research and Community Services at Universitas Sebelas Maret for the financial support.

\section{REFERENCE}

Afriana, J., Permanasari, A., Fitriani, A. (2016). Penerapan Project Based Learning Terintegrasi STEM untuk Meningkatkan Literasi Sains Siswa Ditinjau dari Gender. Jurnal Inovasi Pendidikan IPA. 2(2), 202212.

Astawa, N.L, Artini, L.P, \& Nitiasih, P.K. (2017). Project Based Learning Activities and EFL Students' Productive Skills in english. Journal of Language Teaching and Research, 8(6), 1147-1155.

Alghafri, Rashid,A.S. dan Salim,H.N.B. (2014). "The Effects of Integrating Creative and Critical Thinking on Schools Students Thinking". International Journal of Science and Humanity, 4(6), 518-525.

Birgili, B. (2015). Creative and Critical Thinking Skills in Problem-based Learning Environments, 2(2), 71-80. https://doi. org/10.18200/JGEDC.2015214253
Cahyana, U., (2017). "Relasi Kemampuan Berpikir Kritis dalam Kemampuan Literasi Sains pada Siswa Kelas IV Sekolah Dasar". Jurnal Sekolah Dasar, 26(1), 14-22.

Capraro, R.M. (2013). STEM Project-Based Learning: An Integrated STEM Approach (2nd Edition). Taipei: SensePublisher.

Chiang \& Lee. (2016). "The Effect of Project Based Learning on Learning Motivation and Problem Solving Ability of Vocational High School Students". International Journal of Information and Education Technology, 6(9), 709-712.

Chiappetta,E.L., Koballa, T.R. (2010). Science Instruction in the Middle and Secondary Schools: Developing Fundamental Knowledge and Skills, 7th Edition. New York: Person.

Chu, S.K.W. (2011). "Using Collaborative Teaching and Inquiry Project Based Learning to Help Primary School Students Develop Information Literacy and Information Skills". Elsevier: Library and Information Science Research 33(), 132-143.

Depdiknas. (2011). Panduan pengembangan pembelajaran IPA secara terpadu. Direktorat Jenderal Pendidikan Dasar Depdiknas. Jakarta.

Education For All. 2015. “A Report on Education For All (EFA) Achievementr Period 20002015". Education For All Coordinator Forum Republic of Indonesia.

Fadhilah, U.N. (2017). "Tumbuhkan Budaya Literasi, 19 Daerah dapat Penghargaan". Diakses melalui http:// www.republika.co.id/berita/pendidikan/ eduaction/17/03/20/on 3 um3335 tumbuhkan-budaya-literasi-19-daerahdapat-penghargaan.Fathurohman. (2014). "Analisis Bahan Ajar Fisika SMA Kelas IX di Kecamatan Indralayu Utara Berdasarkan Kategori Literasi Sains". 
Jurnal Inovasi dan Pembelajaran Fisika, 1(1): 43-47.

Fatimah, S. (2018). "The Effect of Project Based Learning on Creative Thinking Skills Toward Preservice Teacher in Primary Teacher Education Program". List of Accepted Papers Jurnal Pendidikan Indonesia. 7 (2).

Gunawan, Sahidu, H., Harjono, A., \& Suranti, N.M.Y.(2017). The Effect of ProjectBased Learning With Virtual Media Assistance on Student's Creativity in Physics. Jurnal Cakrawala Pendidikan. 36(2), 167-179.

Gormally, C. (2012). "Developing a Test of Scientific Literacy Skills (TOSLS): Measuring Undergraduates Evaluation of Scientific Informastion and Arguments". CBE Life Sciences Education, 11(), 364377.

Grant, M.M. (2002). "Getting a Grip on Project Based Learning: Theory, Cases, and Recommendation". Meridian: A Middle School Computer Technologies Journal, (1).

Hake. 2007. Design-Based Research in Physics Education Research.: NSF Grant DUE.

Harper, A. (2014). Using Project Based Learning to Develop Student's Key Competence. Europe: Europe Schoolnet.

Hendrik, P. \& Ihtiari, P. (2016). "Pengaruh Model Pembelajaran Project Based Learning Berbantuan Media Pembelajaran Pembangkit Listrik Tenaga Mikrohidro Terhadap Kemampuan Berpikir Kritis". Jurnal Penelitian Fisika dan Aplikasinya (JPFA), 6(2): 44-50.

Istiyono, E., Dwandaru, W.B., Rahayu, F. (2018). Pengembangan Tes Creative Thinking Skills Fisika SMA (PhysCreTHOTS) Berdasarkan Teori Tes Modern. Jurnal Cakrawala Pendidikan. Th. XXXVII (2): 190-200.
Kashani-vahid, L., Afrooz, G., Shekoohi-yekta, M., Kharrazi, K., \& Ghobari, B. (2017). Can a Creative Interpersonal Problem Solving Program Improve Creative Thinking in Gifted Elementary Students? Thinking Skills and Creativity. https://doi. org/10.1016/j.tsc.2017.02.011

Mihardi, S., Harahap, M.B., \& Sani, R.A. 2013. "The Effect of Project Based Learning Model with KWL Worksheet on Student Creative Thinking Process in Physics Problem". Journal of Education and Practice, Vol 4 (25): 188-200.

Morgil. 2008. The Effect of Web Based Project Aplications on Students Attitudes Towards Chemistry. Turkish Online Journal of Distance Education-Tojde Vol 9 (2), Article 13. Retrieved from http:// rspublication.com/ijst/dec13/39.pdf

Muskania,R.T \& Wilujeng,I. 2017. Pengembangan Perangkat Pembelajaran Project-Based Learning Untuk Membekali Foundational Knowledge Dan Developing A Project-Based Science Learning Kit To Provide Foundational Knowledge And Improve Scientific Literacy, Jurnal Cakrawala Pendidikan, Th. XXXVI (1): 34-43

OECD. 2015. PISA 2015 Result: What Students Know and Can Do-Student Performance in Reading, Mathematics and Scienc. OECD Publishing: Paris.

Rahayuni, G., 2016. "Hubungan Keterampilan Berpikir Kritis dan Literasi Sains Pada Pembelajaran IPA Terpadu dengan Model PBM dan STM". JPPI, Vol 2 (2): 131146.

Rais. 2010. "Project Based Learning: Inovasi Pembelajaran yang Berorientasi Soft Skills". Disajikan sebagai Makalah Pendamping dalam Seminar Nasional Pendidikan Teknologi dan Kejuruan Fakultas Teknik UNESA pada 11 Desember 2010. 
Rohana,R.S \& Wahyudin.D., 2017. "Project Based Learning untuk Meningkatkan Berpikir Kreatif Siswa SD Pada Materi Makanan dan Kesehatan". Jurnal Penelitian Pendidikan LPPM UPI, Vol. 16 (3): 235-243.

Roziqin,M.K., Lesmono.A.D., \& Bachtiar.R.W., 2018. "Pengaruh Model Pembelajaran Berbasis Proyek Terhadap Minat Belajar dan Keterampilan Proses Sains Siswa Pada Pembelajaran Fisika di SMAN Balung". Jurnal Pembelajaran Fisika, Vol 7 (1): 108-115.

See, Y.G, Rashid, A.M, Bakar , A.R. (2015). The Effect of Project Based Learning on Level of Content Knowledge of Pre-Vocational Subject. Mediterranean Journal of Social Sciences Vol 6 (6): 369-375.

Sumarni, W., 2015. "The Strengths and Weaknesses of the Implementation of Project Based Learning: A Review". Internation Journal of Science and Research (IJSR) Vol 4 (3): 478-484.

Suparno, P., 2007. Metodologi Pembelajaran Fisika: Konstruktivistik dan Menyenangkan. Yogyakarta: USD.
Susiati, A, Adisyahputra, dan Miarsyah, M. 2018. "Hubungan Kemampuan Membaca Pemahaman dan Kemampuan Berpikir Tingkat Tinggi dengan Kemampuan Literasi Sains Guru Biologi SMA". BIOSFER: Jurnal Pendidikan Biologi, Vol. 11 (1): 1-12.

Wakhidah, N. 2012. "Keterampilan Membaca dan Menulis dalam Meningkatkan Berpikir Kritis dan Literasi Sains". Prosiding Seminar Nasional Prodi Pendidikan Sains UNESA, hlm: 71-84.

William, S., 2017. "Investigation the Allocation and Corroboration of Individual Grades for Project Based Learning". Studies in Educational Evaluation. Elsevier, 53: 1-9.

Winarni,E. W.2012.Inovasi dalampembelajaran IPA. Bengkulu: FKIP Universitas Bengkulu.

Vignesh dan Jothi,S., 2012. "Implementation of Holographic View in Mobile Video Calls". International Journal of Advanced Research in Computer Science and Software Engineering, Vol. 2 (10): 471478. 